\title{
HOW TO USE THIS DICTIONARY
}

The immediate purpose of this dictionary is not only to make the ideas of Max Weber better known and more easily available to English-speaking readers. It is also our hope that it may inspire our readers to make more use of Weber's insights in their own research. It is not only useful to know what Weber has said on some specific topic and to get to know his work better. It is also imperative to learn how to theorize with the help of Weber, that is, to learn how to use ideas, concepts, and social mechanisms in studying and explaining social reality.

For this last purpose-to help our readers to use Weber for a bit of creative theory construction of their own-we have added a number of new entries to the second edition of this dictionary on the theme of theorizing. In this way we also hope to open up a new avenue of research on Weber, and one that is more practical in nature than much of the existing literature, which often has exegesis as its main purpose. The emphasis in these new entries is on how Weber thought that theorizing should be carried out, and also on how he himself went about developing and constructing his own theories. These entries typically discuss tools for theory construction and how to capture the process of social life with their help. They include, for example, such entries as the following: "analogy," "configuration," "definition (of concepts)," "heuristics," "imagination and creativity," "metaphors," "process, processual," "theorizing,"

1. One reason for taking this stance is that both editors of this dictionary are actively engaged in furthering the project of how to theorize among sociologists and social scientists, as opposed to teaching theory in the old-fashioned manner by simply referring students to the major works and ideas of Marx, Weber, and so on. See, e.g., Richard Swedberg, The Art of Social Theory (Princeton University Press, 2014), (ed.), Theorizing in Social Science (Stanford University Press, 2014), and "How to Use the Ideal Type in Concrete Research" (2014); and Ola Agevall, "Thinking about Configurations: Max Weber and Modern Social Science," Etica \& Politica / Ethics \& Politics 7, 2 (2005), http:// www2.units.it/etica/2005_2/AGEVALL.pdf (accessed February 20, 2016), and "Social Closure: On Metaphors, Professions, and a Boa Constrictor," in Andreas Liljegren and Mike Saks (eds.), Professions and Metaphors: Understanding Professions in Society (London: Routledge, forthcoming). 
and "Weber, Max-Style of Work." We have also added to and/or rewritten many old entries with theorizing in mind, such as "comparisons," "cultural significance (for cultural problems of the time)," "Economy and Society," "ideal type," "concepts," "functionalism," "meaning," "orientation to others," "quote marks and italics in Weber's texts," "rules," "social mechanisms," "types and typologies," "uniformities" and "value-relevance."

If you look at Economy and Society from the perspective of theorizing, we also suggest, it loses some of its mystery. Weber contradicts himself at times in this work; and one reason for this is that it does not constitute a book but a series of manuscripts that Weber produced as he was trying to work out what he wanted to say.

It should be emphasized that the entries in the dictionary have not been written in an attempt to provide the reader with definitive answers to what Weber means by a certain word, concept, or phrase. For a number of reasons this is not possible. The meaning of a specific word or concept depends on the text in which it can be found. Each text is also part of a social and historical context-as well as of Weber's evolving work and his life. Finally, readers are themselves part of another context and have usually some specific purpose in mind when they look up a specific word or concept.

What we have instead tried to do, is to provide our readers with statements and definitions that are as clear as possible, and also to supply references to relevant secondary literature. If Weber has himself provided a definition or a definition-like statement somewhere in his work, we have tried to include it.

Why a second edition of The Max Weber Dictionary? We have already mentioned the need to develop a new attitude to Weber's work, one that is more concerned with theorizing. But there is also the fact that more than a decade has passed since the publication of the first edition of this dictionary (in 2005), and during this period many new and interesting studies of Weber's work have appeared, as well as some new important translations. ${ }^{2}$ Quite a few of these, it should be emphasized, can be found in Max Weber Studies (2000- ), which has continued to be the major place of publication for first-rate studies of Weber and his work.

We now, for example, know quite a bit more about Max Weber's trip to the United States in 1904, primarily thanks to Lawrence Scaff's Max Weber

2. For a review of the first edition, see Hans Henrik Bruun, "Review of The Max Weber Dictionary," Max Weber Studies 7, 1 (2007): 127-32. 
in America (2011). Also, when the first edition of the dictionary was put together, only one biography of Max Weber existed, whereas today there are several. Of these new biographies, only one has so far been translated into English: Joachim Radkau's Max Weber: A Biography (2005; translated in abbreviated form in 2009). This book contains much new material on Weber, not least on his emotional and sexual life.

A few years ago all of Weber's methodological writings were also retranslated in a meticulous and exemplary manner in a volume edited by Hans Henrik Bruun and Sam Whimster, Collected Methodological Writings (2012), which supersedes Essays in the Methodology of the Social Science. We think that modern readers should use Collected Methodological Writings, and the new edition of the dictionary reflects this standpoint.

But most important of all, the German effort to publish a definitive edition of Weber's work, the Max Weber-Gesamtausgabe (MWG), has progressed very quickly during the past few years and is today nearly complete. Not only does this mean that we now have definitive editions of all of Weber's works in their original German; each volume typically also contains a lengthy and well documented introduction. Weber's letters and lecture notes are also annotated and documented in an exemplary manner in the Gesamtausgabe.

All of this new material has made it imperative for us not only to introduce many new references and facts but also to include many new entries. This new edition contains, for example, new entries for "adaptation," "pragmatism," "Du Bois, W. E. B. (1868-1963)," and many more. There is also a very long new entry for "Collected Works (Max Weber-Gesamtausgabe)."

Similarly, we have in some cases found it necessary to rewrite the entries in the first edition. This has, for example, been done with the entries for "elective affinities," "psychophysics," and "race and racism" (replacing the old entry for "race"). The second edition is as a result about 20 percent larger than the first edition.

A typical entry in the dictionary begins with a short summary of what a concept means in Weber's work. This is followed by Weber's definition (if one exists), some explication, and a few references to secondary literature. In each entry the concept or key term is given in English, followed by the German equivalent in parentheses. In choosing definitions from Weber's work priority has been given to his definitions in chapter 1 of Economy and Society, "Basic Sociological Terms." Weber made a huge effort toward the end of his life to develop a new kind of sociology-interpretive sociology- 
and we have decided to prioritize this effort in the dictionary and make it its focus. He was also very interested in making (what we today call) Economy and Society into a textbook, that is, a manual of sorts for how to do research in sociology; and we have tried to follow him in this ambition as well.

Our identities as sociologists have no doubt played a role in this emphasis. Ideally, we would have liked to design the dictionary so as to enable professional economists, political scientists, and legal scholars also to find precisely what they are looking for in Weber's work. We have made a huge effort in this direction, but again, we are sociologists by profession and are most knowledgeable in this type of science.

When Weber's main works are referred to in the text, abbreviations are used. Economy and Society, for example, is cited as ES, and The Protestant Ethic and the Spirit of Capitalism as PE. A full list of abbreviations can be found at the beginning of the dictionary below.

We have tried to use the standard translations of Weber's works into English, since these are the most easily available and also the ones that contain formulations with which many readers are likely to be familiar. In some cases, however, the existing translations are of poor quality and more recent and better translations have had to be used.

After the definition in an entry, there is typically a sentence or two with material that adds to the understanding of the definition or of how Weber used the concept. In choosing secondary literature, we have in the great majority of cases given preference to references in English. We use references in German only if there is no adequate or equivalent text in English. Since the dictionary is primarily aimed at English-speaking readers, it has seemed natural to concentrate on the secondary literature in that language. A Weber dictionary in German would no doubt look different, both in terms of entries and in terms of the secondary literature referred to.

As far as we know, there is no Max Weber dictionary in German. However, the very useful Max Weber-Handbuch (2014) edited by Hans-Peter Müller and Steffen Sigmund contains two huge sections on central concepts in Weber and his major writings, as well as a section with topics that are relevant today and related to Weber. We highly recommend it to those of our readers who know German.

In choosing the secondary literature in our dictionary, we have tried to be selective and not to overload the entries. This means that we have drawn heavily on work by well-known experts on Weber, from Alexander von 
Schelting, Alfred Schutz, Talcott Parsons, and Raymond Aron earlier to Hans Henrik Bruun, Edith Hanke, Dirk Käsler, Klaus Lichtblau, Wolfgang Mommsen, Joachim Radkau, Gunther Roth, Lawrence Scaff, Wolfgang Schluchter, Keith Tribe, and Sam Whimster today. The secondary literature is often referred to in abbreviated form in the text of the entries. For the full details of some item, the reader is referred to the reference list at the end of the dictionary.

Besides entries for concepts that are typically associated with Weber's name (such as "charisma" and "domination"), we have also included entries on topics that Weber interpreted and recast in an innovative manner, and that the reader may therefore be interested in knowing more about (such as "capitalism" and "salvation"). It is this type of entry that we have designated as key words in the subtitle to this dictionary.

Entries have also been added in some cases for terms such as "lytric" and "autocephalous" in Weber's work simply because the average reader may find them useful. The reader may also wonder what Weber thought of "norms" and "institutions," two terms that are often used in today's sociology; and entries have therefore been added for these. Since it is our guess that some readers may expect this dictionary to include entries for Weber's life as well as his main works, we have included a limited number of such entries-as well as a few others that we hope readers may find useful (such as "neo-Kantianism" and "Marxism"). In a few cases we have also given in to our own fascination with details; and the reader who, for example, is interested to know more about Weber's dog Murx can find a reference in the entry for "animals."

As with all thinkers, Weber is finally what his readers make of him. If he is used well, in concrete research as well as in theoretical analyses, this second edition of the dictionary will soon be outdated; and that is what we are hoping for. If not, it will retain its accuracy-and gather dust on some library shelf. 
